the recruitment of patients with a diagnosis of heart failure from general practice. Patients are referred to hospital for confirmation of the diagnosis and enrolled into one of three treatment groups. The doses of enalapril in the different groups are $2.5 \mathrm{mg}$ twice daily, $5 \mathrm{mg}$ twice daily or $10 \mathrm{mg}$ twice daily. The follow up period will last six months. The authors are members of the NETWORK Steering Committee.

The Assessment of Treatment with Lisinopril And Survival (ATLAS) study is comparing low and high dose lisinopril in 3000 patients. Two groups of patients will be compared. The first group will be on low-dose lisinopril (2.5 or $5 \mathrm{mg}$ once daily) and the other group will be on high-dose lisinopril (up to $35 \mathrm{mg}$ once daily). The followup period is three years and the primary endpoint is mortality.

ACE inhibitors have an important role in the treatment of patients with heart failure. They not only improve symptoms and reduce hospital admissions but also extend life. When these two important trials are published we should know what dose of ACE inhibitors to use in order to achieve the maximum benefit for our patients, both in

1 The CONSENSUS (Co-operative New Scandinavian Enalapril Survival Study) Trial Study Group. Effects of enalapril on mortality in severe heart failure. N Engl f Med 1987; 316: 1429-35.

2 Cohn JN, Johnson G, Ziesche S, et al. A comparison of enalapril with isosorbide dinitrate in the treatment of chronic congestive heart failure. (V-HEFT II-Veterans Heart Failure Trial II). N Engl $\mathcal{F}$ Med 1991; 325: 303-10

3 The SOLVD (Studies of Left Ventricular Dysfunction) Investigators. Effects of enalapril on survival in patients with reduced left ventricular ejection fractions and congestive cardiac failure. $N \mathrm{Engl} F \mathrm{Med} 1991 ; 325$ : 293-302.

4 Pfeffer MA, Braunwald E, Moye LA, et al. Effect of captopril on mortality and morbidity in patients with left ventricular dysfunction after myocardial infarct - results of the survival and ventricular enlargement trial. $N$ Engl $f$ infarct - results of the su
Med 1992; 327: $669-77$.

5 The AIRE (Acute Infarction Ramipril Efficacy) Study Investigators. Effect of ramipril on mortality and morbidity of survivors of acute myocardial 6 infarction with clinical evidence of heart failure. Lancet 1993; 342: 821-8. Group. Randomised study of oral captopril in over 50,000 patients with suspected acute myocardial infarction. Circulation 1993; 88 (suppl): 1-394. terms of symptom improvement and prognosis, at least for the two drugs in this category. For the present, doctors should prescribe the doses shown to be beneficial in the large trials.

JGF CLELAND Department of Medicine, Hammersmith Hospital, London, UK WN HUBBARD Royal United Hospital Combe Park, Bath, UK J PITTARD General Practitioner Staines, Middlesex, UK PA POOLE-WILSON Department of Cardiology, National Heart and Lung Institute, London, $U K$ GC SUTTON

Department of Cardiology Hillingdon Hospital, London, UK

7 GISSI-3 (Gruppo Italiano per lo Studio della Sopravvivenza nell'Infarcto Miocardico). Effects of lisinopril and transdermal glyceryl trinitrate singly and together on 6-week mortality and ventricular function after acute myocardial infarction. Lancet 1994; 343: 1115-22.

8 Braunwald E. ACE inhibitors - a cornerstone of the treatment of heart failure. $N$ Engl $₹$ Med 1991; 235: 351-3.

9 Brilla CG, Kramer B, Risler T, Seipel L. Low dose enalapril in severe chronic heart failure. Kardiologie 1991; 80 (suppl 2): 44-9.

10 Pacher R, Globits S, Bergler-Klein J, et al. Clinical and neurohumoral response of patients with severe congestive heart failure treated with two different captopril dosages. Eur Heart $\mathcal{F}$ 1993; 14: 273-8.

11 Vagelos R, Nejedly M, Willson K, Gail Yee Y, Fowler M. Comparison of low versus high dose enalapril therapy for patients with severe congestive heart failure. $₹ \mathrm{Am}$ Coll Cardiol 1991; 17: 275A.

12 Riegger GAJ. Effects of quinapril on exercise tolerance in patients with mild to moderate heart failure. Eur Heart $\mathcal{f}$ 1991; 12: 705-11.

\title{
3 February 1821
}

Elizabeth Blackwell (1821 - 1910) was born in Bristol, UK, the third daughter and third of nine children of a sugar refiner who migrated with his family to the USA in 1832 . She became a medical student at the University of Geneva in the State of New York, where she received a degree (1949) and then returned to England. Her medical training was greatly helped by James Paget at St Bartholomew's Hospital. While a resident at La Maternite hospital, Paris, France, she contracted purulent ophthalmia from a patient and lost one eye. In 1851 she returned to New York and joined her sister in practice. When still in England, her name was included in the British Medical Register, the first woman doctor to be registered. She was present on 11 July 1898 at the new Royal Free Hospital Medical School. She died on May 31, 1910 in Hastings, UK. 